\title{
TAXPAYERS' PERCEPTIONS TOWARDS E-FILING SYSTEM APPLICATION: A DECOMPOSED THEORY OF PLANNED BEHAVIOR (DTPB) APPROACH
}

\author{
Latifah Hanum \\ Dosen Fakultas Ilmu Administrasi Universitas Brawijaya, Malang, Indonesia \\ Email: latifahhanum@ub.ac.id
}

\begin{abstract}
ABSTRAK
Penelitian ini bertujuan untuk menguji persepsi wajib pajak dalam menggunakan sistem e-filing dengan pendekatan model Decomposed Theory of Planned Behavior (DTPB) oleh Taylor dan Todd (1995) sebagai pengembangan dari model yang digunakan oleh Lee (2009), Azmi dan Bee (2010) dan Rana et al. (2015). Penelitian ini menggunakan metode survei dalam pengambilan data. Sampel penelitian ini adalah wajib pajak orang pribadi di Kota Malang (Indonesia) yang pernah menggunakan sistem e-filing dalam pelaporan SPT (Surat Pemberitahuan). Sebanyak 83 data dapat dianalisis menggunakan SPSS versi 23.0. Hasil penelitian ini menunjukkan bahwa persepsi kegunaan, persepsi keuntungan, dan persepsi kontrol perilaku berpengaruh terhadap minat keperilakuan menggunakan sistem e-filing. Sedangkan persepsi kemudahan penggunaan dan persepsi resiko tidak berpengaruh terhadap minat keperilakuan menggunakan sistem e-filing. Hal ini menunjukkan bahwa wajib pajak di kota Malang sebagian besar sudah merasa nyaman dan menerima kehadiran teknologi baru dalam dunia perpajakan khususnya dalam pelaporan SPT. Selain itu wajib pajak menggunakan fasilitas sistem e-filing bukan didasarkan kepada kemudahan penggunaan fasilitas tersebut melainkan lebih disebabkan oleh kegunaan dan kebutuhan atas fasilitas tersebut dalam melaporkan SPTnya, sehingga wajib pajak merasa menggunakan sistem e-filing tidak menimbulkan resiko dalam penggunaannya.
\end{abstract}

Kata Kunci: Technology Acceptance Model (TAM), Theory of Planned Behavior (TPB), Decomposed Theory of Planned Behavior (DTPB), sistem e-filing, minat keperilakuan, persepsi kegunaan, persepsi kemudahan pengguaan, persepsi resiko, persepsi keuntungan, persepsi control perilaku

\begin{abstract}
This research aimed to examine the perceptions of taxpayers in applying the Annual Tax Return e-Filing system with the approach of Decomposed Theory of Planned Behavior (DTPB) model by Taylor and Todd (1995). This research is the development of the model used by Lee (2009), Azmi and Bee (2010), and Rana et al. (2015). The data of this research were collected using a survey method. The sample of this research was individual taxpayers in Malang City (Indonesia) who have been using the Annual Tax Return (SPT) e-Filing system. A total of 83 data were analyzed using SPSS version 23.0. The results showed that the taxpayers' perceived usefulness, perceived benefit, and perceived behavioral control had an effect on behavioral interest or intention to use the e-Filing system. Meanwhile, the taxpayers' perceived ease of use and perceived risk had no effect on the behavioral interest or intention to use the e-Filing system. It indicates that most taxpayers in Malang City have felt comfortable and accepted the presence of new technology in the world of taxation, especially in the reporting of Annual Tax Return. The tendency of taxpayers in Malang City to use the e-Filing system is not based on the perceived ease of use of the facility but rather due to the usefulness and need for such a facility in reporting tax return online, so taxpayers perceive that the e-Filing system does not or will not pose a risk in its use.
\end{abstract}

Keywords: Technology Acceptance Model (TAM), Theory of Planned Behavior (TPB), Decomposed Theory of Planned Behavior (DTPB), e-Filing system, behavioral interest, perceived usefulness, perceived ease of use, perceived risk, perceived benefit, perceived behavioral control 


\section{A. INTRODUCTION}

Taxes have an important role in the revenue of a country. According to Soemitro in Mardiasmoro (2011: 1), taxes are contribution or dues (money) of the people to the state treasury (which can be coercive) with no getting directly demonstrable reciprocal services for common or public interest. The tax sector contributes substantially to state revenues, which can be seen in the State Budget $(A P B N)$ of 2016. The state revenue in 2016 was recorded at IDR $1,822.5$ trillion in which the highest revenue of $75 \%$ or IDR $1,360.2$ trillion resulted from the taxation sector (www.kemenkeu.go.id).

Tax revenue is used to fund the governance and infrastructure development so as to improve the welfare and prosperity of the people of Indonesia. Given the importance of taxes as a source of a country's revenue, the support and participation of all elements of the nation are needed to meet the target of tax revenue. Furthermore, the government is also expected to explore potential tax revenue in various sectors. The following table shows the realization of tax revenue from 2013 to 2016.

Table 1. Percentage of Tax Revenue Realization of 2013-2016 (in IDR Trillion)

Percentage of Tax Revenue Realization

\begin{tabular}{|l|l|c|c|c|}
\hline Year & $\mathbf{2 0 1 3}$ & $\mathbf{2 0 1 4}$ & $\mathbf{2 0 1 5}$ & $\mathbf{2 0 1 6}$ \\
\hline Target & 995.21 & 1.072 .37 & 1.294 .26 & 1.355 .20 \\
\hline Realization & 921.27 & 981.83 & 1.060 .83 & 1.105 .81 \\
\hline Achievement & $92.57 \%$ & $91.56 \%$ & $81.96 \%$ & $81.60 \%$ \\
\hline
\end{tabular}

Source: Directorate General of Taxation, 2016

Based on Table 1 above, it can be seen

that Indonesia's realization of tax revenue from

2013 to 2016 shows an increase in spite of the up and down percentages. Even, the achievement of tax revenue from 2013 to 2016 gradually experienced a decline up to $81.60 \%$ due to the increasing target of tax revenue from year to year. One way to meet the target of tax revenue is to encourage the community as taxpayers to orderly deposit taxes and report their tax return to the Tax Office.

However, in fact, the ratio between the reporting of tax returns in Indonesia and the number of registered taxpayers is still small. It indicates that the taxpayer compliance level in reporting tax returns is also still low. Thus, the state revenue from the tax sector has not been maximally absorbed. Based on the data of the Directorate General of Taxation, the number of taxpayers registered and obliged to report tax return reaches $18,159,840$ people. Of the total number of registered taxpayers, only 10,945,567 people or $60.27 \%$ who report tax returns (www.pajak.go.id)

The data above indicates that the level of taxpayer compliance in reporting Annual Tax Return is still low. Therefore, the Directorate General of Taxation has developed a tax application service to facilitate taxpayers in tax payment and submission through information technology. The application service is made to encourage and attract many more taxpayers to report tax returns to the Tax Office properly and on time. Nowadays, the role of information technology in the world of taxation is highly important to utilize. Information technology can be one of the means of creating competitive advantage so as to improve the people's welfare. To apply information technology in the taxation sector, the Directorate General of Taxation develops e-Filing system technology.

E-Filing is a reporting service of Periodic Tax Return or Annual Tax Return using electronic forms provided through the internet media. E-Filing is one form of self-assessment system-based application of taxation, that is a system intended for taxpayers to calculate, deposit, and report their own taxes without the presence or assistance of tax officials. Specifically, the submission of Annual Tax Return and Renewal Annual Tax Return by eFiling on the Directorate General of Taxation website is governed through Procedures of Annual Tax Return Completion for Individual Taxpayer Using Form 1770S or 1770SS provided in the E-Filing System on the Website of the Directorate General of Taxation (Directorate General of Taxation, 2013).

The process of Annual Tax Return completion through e-Filing system takes a very shorter time compared to the traditional or manual way. The form filing of Annual Tax Return through the internet only takes 30 minutes so that it will increase taxpayer compliance (Tsung Lu, Yan and Yen lo, 2010). Besides, there are many advantages that can be obtained by taxpayers from the use of e-Filing system, two of which are that e-Filing transaction is free of a queue and can be done from anywhere as long as taxpayers have the internet connection.

According to the data on the internet use in Indonesia obtained from a survey conducted by the Association of Indonesia Internet Service Providers $(A P J I I)$, the number of Indonesia's internet users in 2016 reached $51.86 \%$ of the total population of Indonesia 
(www.tekno.kompas.com). The above fact indicates that the number of Indonesian people using information technology system gets increased from year to year. Therefore, the eFiling system technology applied by the Directorate General of Taxation as an internetbased information system should be more widely used by taxpayers. From the above explanation, the researchers were interested and challenged to investigate about the aspects influencing the taxpayer's acceptable behavior in using the eFiling system that has been officially launched by the Directorate General of Taxation in the submission of Annual Tax Return.

The taxpayer's acceptable behavior towards the e-Filing system may have two possibilities, whether they are willing to use it in the future or, otherwise, they are reluctant to use the system. If the e-Filing system is perceived to be useful or easy to use, taxpayers will intend to use it on an ongoing basis. On the contrary, if the e-Filing system is perceived to be complex or difficult to use. They will be reluctant to use it. Furthermore, by knowing the aspects influencing the taxpayer's acceptable behavior towards the e-Filing system, it is expected to give a contribution to the Directorate General of Taxation for the improvement of tax services to taxpayers, especially in terms of Annual Tax Return reporting, and increase the state revenue from the taxation sector.

This information system research is the replication and development of TRA model, that includes TAM, TPB, and DTPB models through the combination of the previous studies. The researchers modified the previous research by combining some variables of Azmi and Bee's (2010) research model (Perceived Usefulness variable, Perceive Ease of Use, and Perceived Risk) with the variable used in Lee's (2009) research model (Perceived Benefit) and the variable used in Rana, Dwivedi, Lal and Williams' (2015) research model (Perceived Behavioral Control). All the variables are independent variables affecting the dependent variable of behavioral interest or intention to use the e-Filing system.

This research focused on examining the determinants of the taxpayer's behavioral interest in using the e-Filing system. Furthermore, the aspects encouraging taxpayers to have an intention to use the information system were also developed from Theory of Acceptance Model (TAM) by Davis (1989), Theory of Reasoned Action (TRA) by Ajzen \&
Fishbein (1980) and Decomposed Theory of Planned Behavior (DTPB) by Taylor and Tood (1995).

Based on the description of the background above, the researcher formulated several statements of problems in line with the research objectives as follows: 1) Does taxpayers' perceived usefulness have a positive effect on the behavioral interest in using e-Filing system?; 2) Does taxpayers' perceived ease of use have a positive effect on the behavioral interest in using e-Filing system?; 3) Does taxpayers' perceived risk have a positive effect on the behavioral interest in using e-Filing system?; 4) Does taxpayers' perceived benefit have a positive effect on the behavioral interest in using e-Filing system?; 5) Does taxpayers' perceived behavioral control have a positive effect on the behavioral interest in using e-Filing system?

\section{B. LITERATURE REVIEW \\ 1. Understanding About Taxation}

According to Law No. 16 of 2009, a tax is a compulsory and coercive contribution to a country that is indebted by individuals or entities under the Act, with no direct reciprocal services or returns and used for the purpose of the greatest possible prosperity of the people of the state. Furthermore, the other definition of taxes according to Dr. Rochmat Soemitro, S.H. is as follows:

"Tax is a contribution (money) of the people to the state treasury (which can be coercive) without getting directly demonstrable reciprocal services for public expenditures" (Resmi, 2011).

From the above understanding, it can be concluded that tax is a compulsory levy. It is usually in the form of money to be paid by people as compulsory contribution or dues to their state of government in respect of income, property ownership, purchase prices of goods, and others (Kartika, 2013). The main elements of the above definition conclude that taxes are (1) dues or charges; (2) levied or posed based on law; (3) coercive; (4) no reciprocal (contracting) services obtained, and (5) to finance public expenditures of the government.

\section{Annual Tax Return (SPT)}

According to Law No. 16 of 2009 on

General Taxation Provisions Article (1) Paragraph (11) and Regulation of the Minister of Finance No. 152/PMK.03/2009, Annual Tax Return $(S P T)$ is a letter used by taxpayers to 
report their own tax calculation and/ or payment, tax objects and/ or non-tax objects, and/or assets and liabilities in accordance with the provisions of the taxation legislation. Annual Tax Return is a means for taxpayers to report and account for the calculation of the amount of their taxes and payments. Taxpayers have the obligation to fill the form of Annual Tax Return correctly, completely and clearly in the Indonesian language using Latin letters and rupiah (IDR) currency units, and they have to sign and submit it to the Tax Office where they are registered. To uniform and facilitate taxpayers in the fulfillment, administration, form, and content of Annual Tax Return, all the documents to be attached and the means used to submit it are ruled in the Regulation of the Minister of Finance.

\section{3. e-Filing}

e-Filing is a service of the submission of

Annual Tax Return electronically both for individuals or entities (corporations or organizations). e-Filing aims to achieve transparency and eliminate the practices of Corruption, Collusion, and Nepotism. E-Filing is a form of self-assessment system-based application of taxation intended for taxpayers to calculate, deposit, and report their own taxes without the presence or assistance of tax officials. Therefore, taxpayers no longer need to come to tax offices for reporting their Annual Tax Return. E-filing is a good idea that makes the submission of tax returns easier and faster. This is because Annual Tax Return data can be submitted anywhere and sent directly to the Directorate General of Taxation database via the internet. The e-Filing data completion includes e-FIN request letter, e-FIN (Electronic Filing Identification Number, e-mail address, e-SPT (Annual Tax Return), and $e-S P T$ receipt.

In another definition, e-Filing is the use of internet technology, world wide web and software of taxation for various tax administration in accordance with the purpose (Tsung Lu et al., 2010), Simply said, e-Filing is the implementation of e-Government in tax administration, especially in Annual Tax Return $(S P T)$ reporting. E-Filing provides advantages to taxpayers, but not all taxpayers use this system. Lai, Obid, and Meera (2004) found that the development of e-Filing is not easy to be accepted by all parties, especially for the lay taxpayers. Thus, tax practitioners are required.
The role of tax practitioners has a significant impact on the success of e-Filing.

\section{Theory of Behavioral Information System}

A behavioral information system is a system describing behavioral aspects of individuals in relation to information systems (Jogiyanto, 2007). A behavioral information system discusses more deeply the actions of information system users from the psychological point of view. The rapid development of the current e-Filing system cannot work or be used when the user's behavioral aspects do not support. This research describes various factors that influence taxpayers' behavioral interest in using e-Filing system. This research was done based on several theories of behavioral information system as follows:

\section{a. Theory of Acceptance Model (TAM)}

Davis (1987) developed Theory of Acceptance Model (TAM) based on the TRA model of Ajzen \& Fishbein (1980). TAM is the most widely used model in research of information systems. TAM developed by Davis (1987) has two variables, namely perceived usefulness and perceived ease of use applied to various contexts of technology acceptance (Amalia, 2010). This model explains that if users are confronted with a new technology, a number of factors will influence their decisions about how and when they will use it. In conclusion, TAM describes that the acceptance of information technology by its users can be affected by certain dimensions.

\section{b. Theory of Planned Behaviour (TPB)}

Theory of Planned Behavior is a theory developed by Ajzen which is a perfection of Theory of Reasoned Action (TRA) proposed by him together with Fishbein. The main focus of Theory of Planned Behavior is the same as Theory of Reasoned Action (TRA), that is related to individual intention to perform certain behaviors. Intentions are considered able reflecting motivational factors that affect behaviors. Intentions are an indication of how hard individuals want to try and how much effort they will make to do a behavior. In Theory of Planned Behavior, Ajzen also added one-factor determining behavioral intention, namely perceived behavioral control. Perceived behavioral control is an individual perception of the control he possesses with respect to certain 
behaviors (Ajzen, 1980). This factor, according to Ajzen, refers to individual perceptions about whether it is easy or difficult to generate certain behaviors. Moreover, this factor is assumed to be a reflection of past experiences and anticipated obstacles. According to Ajzen (1980), there are three factors that can predict individual intentions to perform certain behaviors, namely attitudes, subjective norms, and perceived behavioral control.

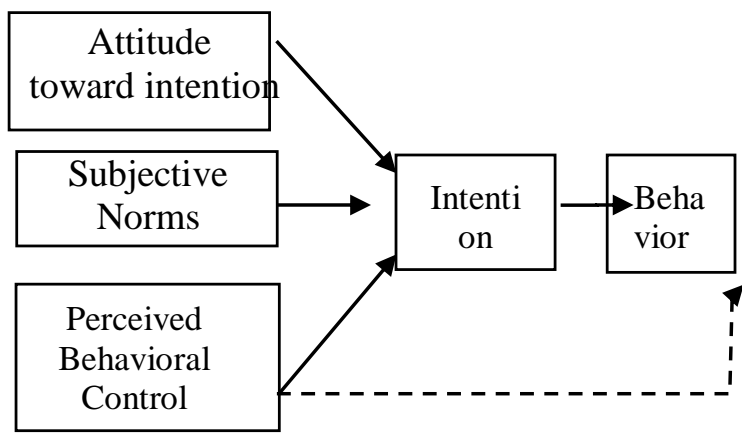

Figure 1. Theory of Planned Behavior (TPB)

\section{c. Decomposed Theory of Planned Behaviour (DTPB) \\ Decomposed Theory of Planned} Behavior (DTPB) was developed by Taylor and Todd (1995) based on Theory of Planned Behavior by Ajzen (1991) which is also the development of Theory of Reasoned Action (TRA) by Fishbein and Ajzen (1980). DTPB is similar to TPB in predicting intentions, but DTPB breaks down or decomposes attitudes, subjective norms, and perceived behavioral control into some sub constructions. For example, Taylor and Todd (1995) decomposed the attitude variable into perceived usefulness, perceived risk, and perceived playfulness. In addition, the perceived behavioral control variable was decomposed into facilitating condition and self-efficacy.

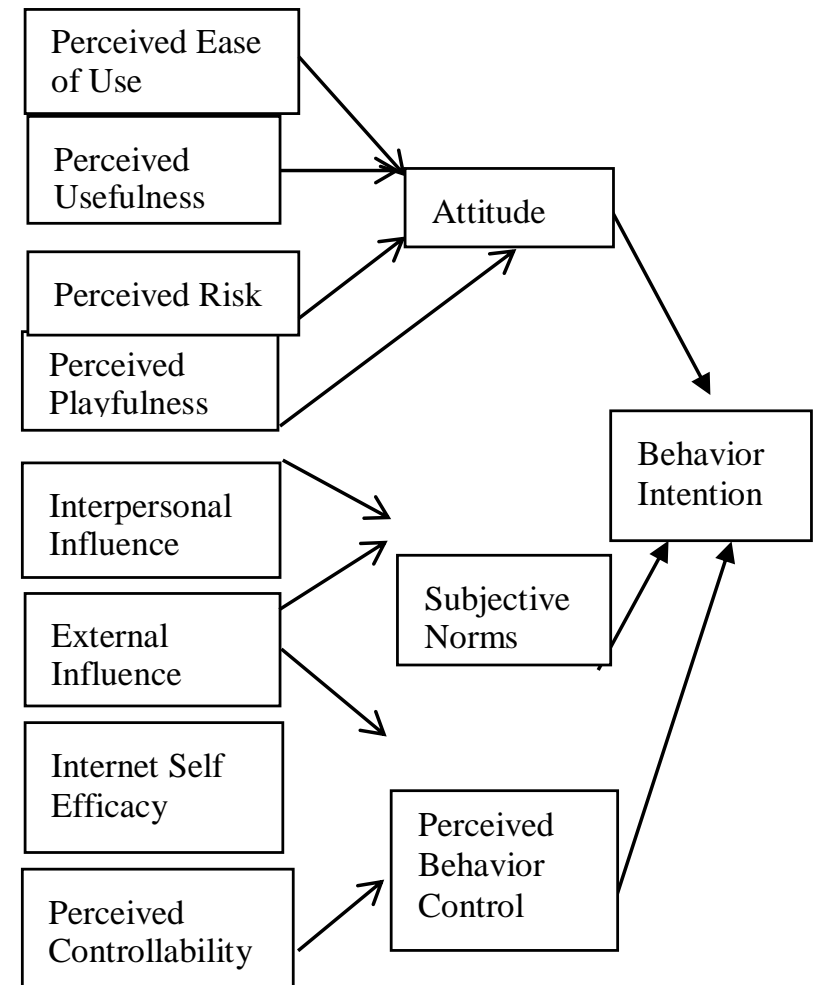

Figure 2. Decomposed Theory of Planned Behavior (DTPB)

\section{Conceptual Framework}

The conceptual framework of this research is the result of replication and modification between the three previous studies on behavioral intention to use e-Filing systems. In this research, the researchers combined all the independent variables that have significant effects of the three previous studies (Azmi and Bee, 2010; Lee, 2009 and Rana et al., 2015). The research model is presented below:

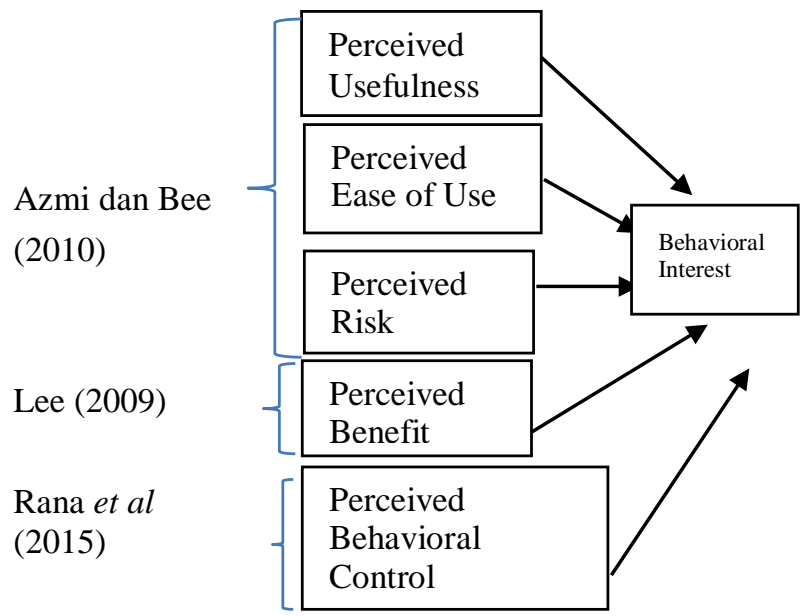

Figure 3. Research Conceptual Framework 


\section{User Acceptance of E-Filing System Information Technology and Development of Hypotheses}

The acceptance of information technology is defined as the comprehensiveness of the spread of a technology in the organizational process which becomes an integral part of the tasks associated with the process (Cooper and Zmud, 1990; Fichman and Kemerer, 1997). in this research, the intended users are taxpayers while the intended information technology is e-Filing. Thus, the understanding of the user acceptance of the information technology is the taxpayer's willingness or desire to use the e-Filing system as a means of tax reporting.

\section{a. Behavioral Interest Concept}

Behavioral interest (intention) is an individual's desire to perform a certain behavior (Jogiyanto, 2007). Behavioral interest measures strength with the aim to perform an action (Tsung Lu et al.,2010). Behavioral interest and behavior itself are two different things. As explained above, behavioral interest is the desire to perform a behavior while behavior is the real action that will be done (Jogiyanto, 2007 in Ananggadipa, 2012). Thus, it can be said that someone will do something if he has the desire from within himself. Jogiyanto (2007) also explained that in previous studies, behavioral interest (intention) is interpreted as a prediction.

\section{b. The Hypothesis of Perceived Usefulness Effect on Behavioral Interest in Using E- Filing System \\ Perceived usefulness is defined by Davis} (1989) as an individual's perception that the use of an information technology will improve the user's performance. Such a perception is based on the subjective probability that a person using an information technology will be easier and get an advantage in an organizational context. Several previous studies, including Azmi and Bee (2010), Lee (2009), Jankeespasrad and Nienaber (2016), have shown that perceived usefulness has a positive and significant effect on attitudes towards the use of technology.

The results of Azmi and Bee's (2010) study show that the perceived usefulness factor has a positive and significant effect on the behavioral interest in using e-Filing system in Malaysia. This is supported by Jankeespasrad $e t$ al.'s (2016) study finding that perceived usefulness is a factor that significantly and positively affects the behavioral interest in using e-Filing system in South Africa. From the previous studies explained above, the researchers then formulated this following alternative hypothesis:

H1: Perceived usefulness has an effect on taxpayers' behavioral interest in using eFiling system.

\section{c. The Hypothesis of Perceived Ease of Use Effect on Behavioral Interest in Using E- Filing System}

Perceived ease of use is the belief that a person using information technology is free from efforts or effortless (Davis, 1989). Meanwhile, according to Tsung Lu et al. (2010), perceived ease of use affects the attitude of a person. Another definition according to Chau et al. (2001) states that perceived ease of use is the extent to which an individual think that using an information system will be free of effort. That is, if someone believes that technology is easy to use, he will use it. Several previous studies, including Azmi and Bee (2010) and Jankeespasrad et al. (2016), have shown that perceived ease of use has a positive and significant effect on attitudes towards the use of technology.

According to Azmi and Bee (2010), the perceived ease of use factor has a positive and significant effect on behavioral interest in using e-Filing system in Malaysia. This is in line with the study conducted by Jankeespasrad et al. (2016) finding that perceived ease of use is a factor determining significantly behavioral interest in using e-Filing system in South Africa. Based on the results of the previous studies, the second hypothesis proposed in this research is as follows:

H2: Perceived ease of use has an effect on taxpayers' behavioral interest in using eFiling system.

\section{d. The Hypothesis of Perceived Risk Effect on Behavioral Interest in Using E-Filing System}

Perceived risk can be defined as the perception of uncertainties and consequences that will be faced after having a certain activity (Hsu and Chiu, 2004). Saraswati and Baridwan (2013) used perceived risk as a substitute for risk because a risk is difficult to catch as a definite target (Hsu and Chiu, 2004). Lee (2009) explained that perceived risks, especially those of fraudulent acts in the internet world, are 
getting higher from day to day. This generates an assumption that a person's perceived risk is what causes the person to be reluctant or unwilling to use an e-Filing system.

Several previous studies, such as Azmi and Bee (2010), Lee (2009) ad Gefen et al. (2003), have shown that perceived risks have a negative and significant effect on behavioral interest in using technology-based information system. However, Belanger and Carter's (2008) study has different results. Based on Azmi and Bee's (2010) study, the perceived risk factor drives a positive and significant effect on behavioral interest in using e-Filing system in Malaysia. Similarly, the study conducted by Geefen et al. (2003) also suggest that perceived risks affect behavioral interest in using e-mail. Considering the results of the previous studies, the researchers formulated the third hypothesis as follows:

H3: Perceived risk has an effect on taxpayers' behavioral interest in using e-Filing system.

\section{e. The Hypothesis of Perceived Benefit Effect on Behavioral Interest in Using E- Filing System}

According to Saraswati and Baridwan (2013), the consumer's perceived benefit in using the internet for business transaction variation compared to traditional shopping is the increased comfort, cost savings, time savings, and increased product that customers can feel or get. The latest development in internet-based transaction technology has brought a lot of potential profitability for the governance system, that is in the taxation sector. It can be seen from the increased speed of transactions, better information, and transparency. Taxpayers will choose to use the e-Filing system if they perceive that the system provides more benefits than the manual or tradition method.

Several previous studies, including Azmi and Bee (2010) and Lee (2009), have suggested that perceived benefits have an effect on behavioral interest in using e-Filing system in Malaysia. Therefore, it can be concluded that perceived benefits have a positive and significant effect on behavioral interest in using e-Filing system. From the results of the previous studies, the four hypothesis below was formulated in this research:

H4: Perceived benefit has an effect on taxpayers' behavioral interest in using e-Filing system.

\section{f. The hypothesis of Perceived Behavioral Control Effect on Behavioral interest in using E-Filing}

Perceived behavioral control is defined as perceived ease or difficulty in performing a behavior (Ajzen, 1991). In the context of information system research, perceived behavioral control can also be interpreted as internal perceptions and external obstacles of a behavior (Taylor and Todd, 1995). Several previous research, such as Rana et al. (2015), Suki and Ramayah (2010) and Hastuti, Suryaningrum, and Susilowati (2014), have examined the effect of perceived behavioral control on behavioral interest.

The results of Rana et al. 's (2015) study show that perceived behavioral control has a significant effect on the user's behavioral interest in using e-Filing system in India. This is supported by the studies of Suki and Ramayah (2010) and Hastuti et al. (2014). Considering the results of the previous studies explained above, the next hypothesis formulated in this research is as follows:

H5: Perceived behavioral control has an effect on taxpayers' behavioral interest in using eFiling system.

\section{RESEARCH METHOD \\ 1. Research Design}

This research used an explanation pattern (level of explanation), that is aimed to explain the position of the variables studied and the relationship between the variables (Sugiyono, 1999), In this case, this research gives an explanation about the effect of the independent variables, covering perceived usefulness, perceived ease of use, perceived risk, perceived benefit and perceived behavioral control on behavioral interest in using e-Filing system.

\section{Population and Sample}

The population in this research was all the e-Filing system users in Malang City with no certain known number (infinite). Malang City was chosen as the research object because it is the biggest city in East Java which currently has quite good economic growth. According to the report of Malang City Revenue Body, the state revenue resulting from the tax sector is quite hight.

The number of the sample of this research was determined by the sample calculation for the uncertainly known population. The reason for the use of the sample calculation was that the 
population of e-Filing users could not be definitely known due to the increasing users from year to year. Therefore, to get the correct and representative sample, the sample number must be determined using the unknown population formula (Riduwan, 2009: 66) as follows:

$$
\begin{aligned}
n & =\left[\frac{Z^{\alpha} / 2 \sigma^{\sigma}}{e}\right]^{2} \\
& =\left[\frac{(1,96)(0,25)}{0,05}\right]^{2}=96,04
\end{aligned}
$$

(rounded to 100)

\section{Description :}

$\mathrm{n} \quad=$ Number of sample

$Z \alpha / 2=$ Confidence level at $\alpha=0,05$

$(95 \%$ confidence level means $Z 0,05 / 2=Z_{0,025}$, a number of 1.96

found in the table)

$\sigma=$ Standard deviation

e $=$ Standard error or tolerated error $(5 \%=$ $0.05)$

From the sample calculation using the formula above, it was obtained a sample size of 96.04. The sample size was then rounded to 100 , meaning that the sample of this research reached 100 users (taxpayers). As for the sample distribution, this research used a snowballing sampling method, which was carried out by collecting the sample or respondents derived from the reference of a network such as the researchers' relatives and partners working in the Tax Office of Malang City. The distribution began with one respondent or reference, then developing into two or three respondents just like a rolling snowball.

Furthermore, the sampling of this research was done by using a purposive sampling technique, that is a sampling technique with a certain consideration (Sugiyono, 2015: $85)$. The sample of this research was taken with the criteria as follows: 1) individual registered taxpayers; 2) have ever used e-Filing system; 3) willing to continue to use the e-Filing system for now and in the future.

\section{Data Collection Method}

The data of this research were collected using a survey data calculation technique. The data were obtained by distributing questionnaires to the e-Filing system users (taxpayers who already have Taxpayer
Identification Number/ NPWP and have been using the e-Filing system located in Malang City). The questionnaires used in this research were adopted from the questionnaires of the previous studies. Before the questionnaires distributed to the respondents, the researchers conducted a pilot test to the research instruments to determine the validity and reliability (validity and reliability tests). In the pilot test, the researchers distributed the questionnaires to 30 respondents who have been using the e-Filing system. This research used a closed-ended question type that can be analyzed quantitatively, using a 7-point Likert scale technique covering (1) Very Disagree, (2) Disagree, (3) Somewhat Disagree, (4) Neutral, (5) Somewhat Agree, (6) Agree, and (7) Very Agree.

\subsection{Operational Variable Definition}

The variables used in this research are consistent with the combination of the previous studies of Azmi and Bee (2010), Lee (2009), and Rana et al. (2015) developed through Theory of Acceptance Model (TAM) by Davis (1989), Theory of Reasoned Action (TRA) by Ajzen and Fishbein (1980) and Decomposed Theory of Planned Behavior (DTPB) by Taylor and Tood (1995). The instruments used to measure the constructs of this research were modified from the instruments used in the previous studies. It is further explained in the following table:

Table 2. Questionnaire Item Source of Research Variables

\begin{tabular}{|c|c|c|}
\hline Variable & $\begin{array}{c}\text { Indicator/ } \\
\text { Construct }\end{array}$ & $\begin{array}{c}\text { Questionnaire } \\
\text { Source }\end{array}$ \\
\hline $\begin{array}{c}\text { Independent } \\
\text { Variables }\end{array}$ & $\begin{array}{c}\text { Perceived } \\
\text { Usefulness }\end{array}$ & Lue et al. (2010) \\
\cline { 2 - 3 } & $\begin{array}{c}\text { Perceived } \\
\text { Ease of Use }\end{array}$ & Lue et al. (2010) \\
\cline { 2 - 3 } & $\begin{array}{c}\text { Perceived } \\
\text { Risk }\end{array}$ & Lee et al. (2009) \\
\cline { 2 - 3 } & $\begin{array}{c}\text { Perceived } \\
\text { Benefit }\end{array}$ & Lee et al. (2009) \\
\cline { 2 - 3 } & $\begin{array}{c}\text { Perceived } \\
\text { Behavioral } \\
\text { Control }\end{array}$ & $\begin{array}{c}\text { Rana } \text { et al } \\
(2015)\end{array}$ \\
\hline $\begin{array}{c}\text { Dependent } \\
\text { Variable }\end{array}$ & $\begin{array}{c}\text { Behavioral } \\
\text { Interest }\end{array}$ & $\begin{array}{c}\text { Lue } \text { et al. } \text { (2010) } \\
\text { and Rana } \text { et al. } \\
(2015)\end{array}$ \\
\hline
\end{tabular}

Source: The Researcher's Processed Data (2017)

\section{Data Analysis Technique}

The researchers used a regression analysis using SPSS Version 17.0 software. The hypothesis testing was done in five stages. 
Firstly, the calculation of descriptive statistics was done to give a description of the demographics and the characteristics of the respondents. Secondly, it was conducted validity and reliability tests. Both tests aim to test the validity and reliability of data so as not to be biased. In the third stage, a classical assumption test was performed. After that, the researcher performed a multiple regression test and then started to test the hypotheses. Through this series of tests, the hypothesis testing could be done in more detail for each scenario. In the fifth stage, the analysis results were discussed by giving support of scientific logic on the results of the statistical calculation so as to produce accurate and communicative conclusions. The last stage was validating the research results to provide a high level of scientific conviction over the research results.

\section{DISCUSSION}

\subsection{Description of Respondent Demographic Data}

The respondents of this research were taxpayers in Malang City who have been using electronic filing (e-Filing) in the reporting activity of Annual Tax Return. The questionnaires were directly distributed to the respondents. Of the total 94 questionnaires returned, only 83 questionnaires were able to be processed further.

Of the total respondents, $49 \%$ were male respondents and $51 \%$ were female respondents. In terms of age, $33 \%$ of the respondents were 20 30 aged, $29 \%$ were $31-40$ aged, $22 \%$ were 41 50 aged, $10 \%$ were 51-60 aged, 5\% were under the age of 20 , and the rest $2 \%$ were above the age of 60 . The last educational backgrounds of the respondents also varied. Of the total respondents, 7\% were Senior High School (SMA) graduates, 5\% had Associate Degree (D3), 46\% earned Bachelor's Degree (S1), 34\% earned Master's Degree (S2), and the remaining 8\% had Doctoral Degree (S3). The respondents given the questionnaires also came from various jobs. Majority of the respondents (55\%) were Civil Servants $(P N S)$, the other $34 \%$ were private employees, $1 \%$ worked as an entrepreneur, and the rest $8 \%$ had other professions. Most of the respondents $(53.01 \%)$ knew first the e-Filing system from the Tax Office. The other $30.12 \%$ of the respondents got the first information of eFiling system from their friends. The rest $14.46 \%$ and $2.41 \%$ knew the system respectively from mass media and other sources. All the respondents have been using the e-Filing system in reporting their Annual Tax Return for different periods of time. Of the respondents, $16 \%$ have been using the e-Filing system for less than 1 year, $57.83 \%$ have been using the e-Filing system for 1-3 years, while the remaining $25.30 \%$ have been using it for more than 3 years.

\subsection{Validity and Reliability Tests}

From the results of both instrument validity and reliability tests of this research, all the instruments used in this research were valid and reliable. The results of the validity and reliability tests are further explained as follows:

\subsubsection{Validity Test}

From the instrument validity test to the 83 respondents, it was obtained that all the instruments used in this research were valid, indicated by the correlation value result that was greater than 0.3 (Nurniah, 2005). In more detail, the validity test results are presented in Table 3 .

Table 3. Validity Test

\begin{tabular}{|c|c|c|c|}
\hline \multirow[b]{2}{*}{ Variable } & \multirow[b]{2}{*}{ Item } & \multicolumn{2}{|c|}{ Validity } \\
\hline & & $\begin{array}{c}\text { Correlation } \\
(\mathbf{R})\end{array}$ & Significance \\
\hline \multirow{6}{*}{ (X1) } & $\mathrm{X} 1.1$ & 0.807 & 0.000 \\
\hline & $\mathrm{X} 1.2$ & 0.852 & 0.000 \\
\hline & $\mathrm{X} 1.3$ & 0.738 & 0.000 \\
\hline & $\mathrm{X} 1.4$ & 0.795 & 0.000 \\
\hline & $\mathrm{X} 1.5$ & 0.668 & 0.000 \\
\hline & $\mathrm{X} 1.6$ & 0.766 & 0.000 \\
\hline \multirow{5}{*}{ (X2) } & $\mathrm{X} 2.1$ & 0.891 & 0.000 \\
\hline & $\mathrm{X} 2.2$ & 0.876 & 0.000 \\
\hline & $\mathrm{X} 2.3$ & 0.847 & 0.000 \\
\hline & $\mathrm{X} 2.4$ & 0.905 & 0.000 \\
\hline & $\mathrm{X} 2.5$ & 0.876 & 0.000 \\
\hline \multirow{3}{*}{ (X3) } & X3.1 & 0.776 & 0.000 \\
\hline & X3.2 & 0.841 & 0.000 \\
\hline & X3.3 & 0.873 & 0.000 \\
\hline \multirow{3}{*}{ (X4) } & $\mathrm{X} 4.1$ & 0.772 & 0.000 \\
\hline & $\mathrm{X} 4.2$ & 0.789 & 0.000 \\
\hline & $\mathrm{X} 4.3$ & 0.777 & 0.000 \\
\hline \multirow{3}{*}{ (X5) } & X5.1 & 0.650 & 0.000 \\
\hline & X5.2 & 0.798 & 0.000 \\
\hline & $\mathrm{X} 5.3$ & 0.765 & 0.000 \\
\hline \multirow{5}{*}{$(\mathrm{Y})$} & $\mathrm{Y} 1$ & 0.375 & 0.000 \\
\hline & $\mathrm{Y} 2$ & 0.742 & 0.000 \\
\hline & $\mathrm{Y} 3$ & 0.820 & 0.000 \\
\hline & Y4 & 0.861 & 0.000 \\
\hline & Y5 & 0.789 & 0.000 \\
\hline
\end{tabular}

Source: Processed Primary Data (2017) 
From the table above, it can be seen that all the question items for the variable of information quality have a correlation value greater than 0.3 . It means that all the question items for the variables of Perceived Usefulness, Perceived Ease of Use, Perceived Risk, Perceived Benefit, Perceived Behavioral Control, and Behavioral Interest were valid for further testing.

\subsubsection{Reliability}

To pass the reliability test, the Cronbach's Alpha coefficient value in this research model should be greater than 0.6 (Sekaran, 2003). In Table 4. below, it can be seen that there are three variables with a Cronbach's Alpha coefficient value above 0.7. Meanwhile, each of the other three variables has respectively a Cronbach's Alpha coefficient value above $0.9,0.8$, and 0.6. Thus, the instruments of this research can be said quite reliable.

Table 4. Reliability Test

\begin{tabular}{cc}
\hline Variable & $\begin{array}{c}\text { Cronbach's Alpha } \\
(>\mathbf{0 . 7} \text { or }>\mathbf{0 . 8})\end{array}$ \\
\hline Perceived Usefulness & 0.859 \\
Perceived Ease of Use & 0.925 \\
Perceived Risk & 0.776 \\
Perceived Benefit & 0.663 \\
Perceived Behavioral Control & 0.716 \\
Behavioral Interest & 0.730 \\
\hline
\end{tabular}

Source: Processed Primary Data (2017)

\subsection{Classical Assumption Test}

One of the conditions to use a multiple regression equation is the fulfillment of classical assumptions. To obtain an unbiased and efficient value (Best Linear Unbiased Estimator/ BLUE) of one multiple regression equation with a least square method, it is necessary to perform a test to determine whether the regression model resulted can meet the requirements of the classical assumption. The steps taken in the classical assumption test are as follows:

\subsubsection{Data Normality Test}

A normal distribution is the theoretical distribution of continues random variables (Dajan, 1986). The curves representing normal distribution are symmetrically shaped curves. Whether the sample is normally distributed can be determined by looking at the comparison of Normal Probability Plot with the cumulative distribution of the actual data and that with the cumulative distribution of the normal distribution. Normal distribution will shape a straight diagonal line and the plotting data will be compared with the diagonal line. If the data distribution is normal, the line representing the real data will follow the diagonal line (Ghozali, 2012). Here is the calculation result using Normal Probability Plot:

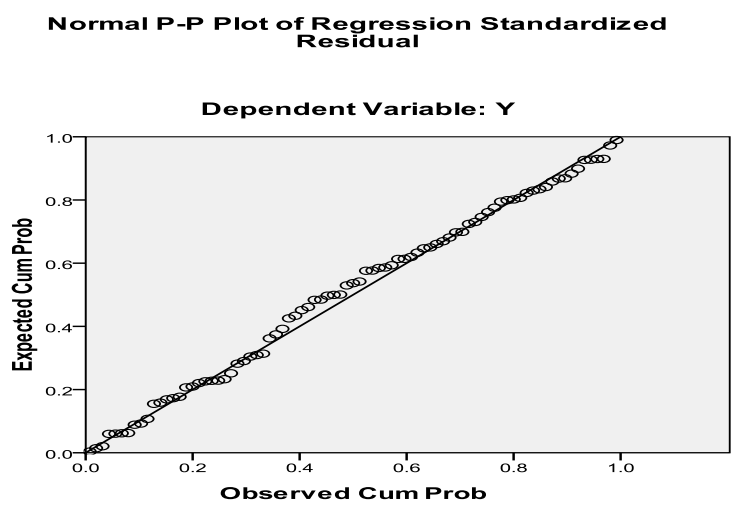

Figure 4. Data Normality Test

Source: Processed Primary Data (2017)

As seen in Figure 4. above, all the data are normally distributed because all the data spread following the diagonal line or normality line. Thus, it can be concluded that this model is normally distributed or meet the assumption of normality, so multiple linear regression can be done.

\subsubsection{Multicollinearity Test}

Multicollinearity can be tested by calculating VIF (Variance Inflating Factors). If the value of VIF $>10$, multicollinearity will occur. And vice versa, if the value of VIF $<10$, there will be no multicollinearity (multicollinearity). Table 5 below presents the VIF and tolerance values of each variable ( Perceived Usefulness, Perceived Ease of Use, Perceived Risk, Perceived Benefit, Perceived Behavioral Control, and Behavioral Interest).

Table 5 Non-Multicollinearity Test

\begin{tabular}{|c|c|c|}
\hline \multirow[t]{2}{*}{ Variable } & \multicolumn{2}{|c|}{ Collinearity Statistics } \\
\hline & Tolerance & VIF \\
\hline Perceived Usefulness & 1.000 & 1.831 \\
\hline Perceived Ease of Use & 1.000 & 1.635 \\
\hline Perceived Risk & 1.000 & 1.127 \\
\hline Perceived Benefit & 1.000 & 1.679 \\
\hline $\begin{array}{l}\text { Perceived Behavioral } \\
\text { Control }\end{array}$ & 1.000 & 1.376 \\
\hline Behavioral Interest & 1.000 & 1.831 \\
\hline
\end{tabular}

Source: Processed Primary Data (2017)

From the table above, it can be seen that there is no multicollinearity occurring for the variables of Perceived Usefulness, Perceived 
Ease of Use, Perceived Risk, Perceived Benefit, Perceived Behavioral Control and Behavioral Interest since the VIF values of the six variables are less than 10 (VIF < 10) and the tolerance values are smaller than and similar to 1 (tolerance $\leq 1$ ).

\subsubsection{Heteroscedasticity Test}

Ghozali (2012) argued that heteroscedasticity test aims to examine whether there is a variance inequality of residual between one observation and another observation in the regression model. If the variance of residual between one observation and another observation is fixed, it is called homoscedasticity. If it is different, it is called heteroscedasticity. A good regression model is a homoscedasticity or nonheteroscedasticity.

Detection of heteroscedasticity can be done by knowing the presence of a particular pattern on the graph, where $\mathrm{X}$-axis is predicted $\mathrm{Y}$, and $\mathrm{X}$-axis is the studentized residual (predicted Y - the actual Y) (Ghozali, 2012). The result of the heteroscedasticity is presented in

the

followinggraph:

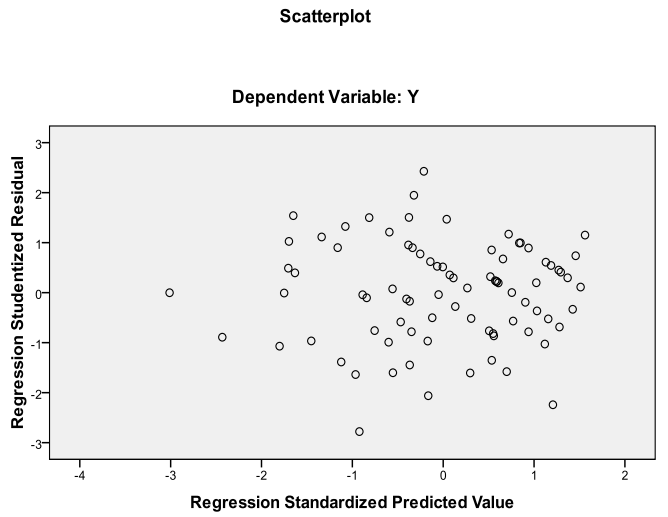

Figure 5 Non-Heteroscedasticity Test

Source: Processed Primary Data (2017)

In Figure 5 above, it can be seen spots that spread randomly either above or below the number of 0 (zero) on the $\mathrm{Y}$-axis and do not shape a certain clear pattern. It indicates no heteroscedasticity occurring on the regression model. Thus, it can be said that the regression model is suitable to predict the behavioral interest in using e-Filing system.

\subsection{Multiple Regression Test}

Because the data met the classical assumption test, the next stage was to conduct a multiple linear regression test. The results of the regression test can be seen in the table below:
$Y=3,695+0,164 X_{1}+0,084 X_{2}+0,086 X_{3}+$ $0,426 X_{4}+0,301 X_{5}+e$

From the equation above, it can be explained that the independent variables affecting the dependent variable can be perceived by the values of Regression Coefficient, Multiple Correlation Coefficient of $\mathrm{r}$ (Multiple R), Determination Coefficient (R square $=r^{2}$ ) and Adjusted R square. Here is the explanation of each regression analysis.

\section{Regression Coefficient}

The greatest regression coefficient value of 0.426 resulted from the Perceived Benefit variable, followed by those resulted from the variables of Perceived Behavioral Control, Perceived Usefulness, Perceived Ease of Use, and Perceived Risk which were respectively $0.301,0.164,0.84$, and 0.86 .

2. Multiple Correlation Coefficient (Multiple R)

The $\mathrm{R}$ value obtained 0.798 , indicating a large degree of effect between the dependent variable (Behavioral Interest) and the independent variables (Perceived Usefulness, Perceived Ease of Use, Perceived Risk, Perceived Benefit, Perceived Behavioral Control). In other words, the effect of the independent variables on the dependent variable was strong. The effect is considered strong because the number is above 0.5 (Santoso, 2004). The positive $R$-value indicates that if the independent variables increase, the dependent variable will also increase, and vice versa.

3. Determination Coefficient $\left(\mathbf{R}\right.$ Square $\left.=\mathbf{r}^{\mathbf{2}}\right)$ Based on the data processing results, the $\mathrm{r}^{2}$ value obtained 0.636 , indicating that the proportion of the Behavioral Interest variable that can be explained by the variables of Perceived Usefulness, Perceived Ease of Use, Perceived Risk, Perceived Benefit, Perceived Behavioral Control was equal to $63.6 \%$. Meanwhile, the remaining $36.4 \%$ can be explained by other variables outside the regression model.

4. Adjusted $R$ Square

Adjusted $R$ Square is used if the number of independent variables is more than two because Adjusted R Square is always smaller than R Square (Santoso, 2004). The effect of the independent variables (Perceived Usefulness, Perceived Ease of Use, Perceived Risk, Perceived Benefit, Perceived 
Behavioral Control) on the dependent variable (Behavioral Interest) showed an Adjusted R Square value of 0.612 .

\subsection{Hypothesis Testing}

The hypothesis testing results were also tested using the F-test (Overall Significance Test) and t-test (Partial Individual Test). The results of the F-test and t-test are explained further below.

\subsubsection{F-Test (Overall Significance Test)}

This testing aimed to determine whether all independent variables included in this research model simultaneously or together had an effect on the dependent variable. At the $\alpha$ level of 0.05 or $\alpha=5 \%$, the results showed a Fvalue of 26,911 and a significance value of 0.000 , indicating that the significance value $<\alpha$ $(0.000<0.05)$. The F-test results indicated that the variables of Perceived Usefulness, Perceived Ease of Use, Perceived Risk, Perceived Benefit, Perceived Behavioral Control simultaneously affected the variable of Behavioral Interest in using e-Filing system.

\subsection{2. $\quad t$-Test (Partial Individual Test)}

To determine whether the independent variables individually had a significant effect on the dependent variable, a t-test was performed. The following table shows the results of the t-test at the significance level $(\alpha)$ of $5 \%$ in the hypothesis testing and the hypothesis changes.

Table 6 Hypothesis Testing Results

\begin{tabular}{|c|c|c|c|}
\hline & Hypothesis & $\begin{array}{l}\text { Sig } \\
\mathbf{t}\end{array}$ & Des. \\
\hline$\left(\mathbf{H}_{1}\right)$ & $\begin{array}{l}\text { Perceived Usefulness } \\
\rightarrow \text { Behavioral Interest }\end{array}$ & 0.003 & Accepted \\
\hline$\left(\mathbf{H}_{2}\right)$ & $\begin{array}{l}\text { Perceived Ease of Use } \\
\rightarrow \text { Behavioral Interest }\end{array}$ & 0.113 & Rejected \\
\hline$\left(\mathbf{H}_{3}\right)$ & $\begin{array}{l}\text { Perceived Risk } \rightarrow \\
\text { Behavioral Interest }\end{array}$ & 0.088 & Rejected \\
\hline$\left(\mathbf{H}_{4}\right)$ & $\begin{array}{l}\text { Perceived Benefit } \rightarrow \\
\text { Behavioral Interest }\end{array}$ & 0.001 & Accepted \\
\hline$\left(\mathbf{H}_{5}\right)$ & $\begin{array}{l}\text { Perceived Behavioral } \\
\text { Control } \rightarrow \text { Behavioral } \\
\text { Interest }\end{array}$ & 0.001 & Accepted \\
\hline \multicolumn{4}{|c|}{ Source: Processed Primary Data (2017) } \\
\hline
\end{tabular}

Hypothesis 1: The Effect of Perceived Usefulness on Behavioral interest in using $E$ Filing System

The Perceived Usefulness variable was hypothesized through $\mathrm{H}_{1}$. From the analysis of
Table 4.4, it is known that the significance value (t-value) of this hypothesis was 0.003 . Because the $\mathrm{t}$-value was less than $5 \%(0.003<0.05), \mathbf{H}_{1}$ was accepted. The hypothesis testing results of $\mathbf{H}_{1}$ indicate that the perceived usefulness significantly affected the behavioral interest in using e-Filing system. It means that the attitudes felt by taxpayers towards the use of e-Filing system have an impact on their behavioral interest in using it. As a result, the more the taxpayers feel liking or being helpful with the use of the e-Filing system, the higher their behavioral interest in using the Annual Tax Return e-Filing system will be.

Hypothesis 2: The Effect of Perceived Usefulness on Behavioral Interest in Using eFiling System

The Perceived Ease of Use variable was hypothesized through $\mathrm{H}_{2}$. From the analysis of Table 4.4, it is obtained that the significance value ( $\mathrm{t}$-value) reached 0.113 . Because the $\mathrm{t}$ value was more than $5 \%(0.113>0.05), \mathbf{H}_{2}$ was rejected. The hypothesis testing results of $\mathrm{H}_{2}$ suggest that the perceived ease of use insignificantly affected the behavioral interest in using e-Filing system. That is, the e-Filing system was considered difficult to use or providing less ease for its users (taxpayers), causing them to have no behavioral interest in using it. Thus, the less ease perceived by taxpayers towards the use of e-Filing system can lead to the lower behavioral interest in using eFiling system in the submission of Annual Tax Return.

\section{Hypothesis 3: The Effect of Perceived Risk on Behavioral interest in using E-Filing System}

The Perceived Risk variable was hypothesized through $\mathrm{H}_{3}$. From the analysis of Table 4.4, it can be seen that the significance value (t-value) reached 0.088 . Because the $\mathrm{t}$ value was more than $5 \%(0.088>0.05), \mathbf{H}_{3}$ was rejected. The hypothesis testing results of $\mathrm{H}_{3}$ indicate that the perceived risk had no significant effect on behavioral interest in using e-Filing system. In other words, the e-Filing system was perceived to be risky or less secure by taxpayers, Therefore, the taxpayer's behavioral interest in using it was very low. Thus, the less secure the e-Filing system is perceived by taxpayers, the lower the taxpayer's behavioral interest in using it in the submission of Annual Tax Return. 
Hypothesis 4: The Effect of Perceived Benefit on Behavioral interest in using E-Filing System

The Perceived Benefit variable was hypothesized through $\mathrm{H}_{4}$. From the analysis of Table 4.4, it is known that the significance value (t-value) was 0.001 . Because the $t$-value was less than $5 \%(0.001>0.05), \mathbf{H}_{4}$ was accepted. The hypothesis testing results of $\mathbf{H}_{4}$ show that the perceived benefit had a significant effect on the behavioral interest in using the e-Filing system. This explains that the comfort or advantages perceived by taxpayers in using the e-Filing system significantly affect their behavioral interest in using it. Thus, the more the taxpayers perceive comfort to use the e-Filing system, the higher their behavioral interest in using it in the submission of Annual Tax Return.

\section{Hypothesis 5: The Effect of Perceived Behavioral Control on Behavioral interest in using E-Filing System}

The Perceived Behavioral Control variable was hypothesized through $\mathrm{H}_{5}$. From the analysis of Table 4.4, it is known that the significance value (t-value) was 0.001 . Because the $\mathrm{t}$-value was less than $5 \%(0.001>0.05), \mathbf{H}_{5}$ was accepted. The hypothesis testing results of $\mathbf{H}_{5}$ indicate that the perceived behavioral control had a significant effect on the behavioral interest in using the e-Filing system. That is, the knowledge and ownership of the device to be prepared by taxpayers in using the e-Filing system significantly affect the taxpayer's behavioral interest in using it. Thus, the greater knowledge and ownership of the device to support an individual to use e-Filing system will increase his behavioral interest in using it in the submission of Annual Tax Return.

\subsection{Discussion of Hypothesis Testing Results}

This research examined the taxpayer perceptions in using the e-Filing system. The taxpayer perceptions towards the use of e-Filing system include Perceived Usefulness, Perceived Ease of Use, Perceived Risk, Perceived Benefit, Perceived Behavioral Control. This research successfully proves that Perceived Usefulness, Perceived Benefit, Perceived Behavioral Control significantly affect the behavioral interest in using the e-Filing system. Meanwhile, Perceived Ease of Use and Perceived Risk are proven not to affect the behavioral interest in using the e-Filing system.
In general, the researcher's success in conduction this study is to prove that Perceived Usefulness, Perceived Ease of Use, Perceived Risk, Perceived Benefit, Perceived Behavioral Control have an effect on Behavioral interest in using e-Filing system due to the development of information system technology applied in all information system contexts, so do the previous studies. Here is the discussion about the effect of each variable on the behavioral interest in using the e-Filing system.

\subsubsection{Discussion of Hypothesis 1: The Effect of Perceived Usefulness on Behavioral Interest in Using E-Filing System}

Perceived Usefulness in this research is defined as the perception used by someone (taxpayer) that the use of the e-Filing system will increase the user performance in reporting Annual Tax Return. The testing results obtained empirical evidence that the hypothesis $\left(\mathrm{H}_{1}\right)$ obtained a significance value of 0.003 . The results are consistent with studies conducted by Fu et al. (2006), Wiyonozz et al. (2008), Hung et al. (2006), Azmi and Bee (2010), Ananggadipa (2012) and Jankeespasrad et al. (2016).

The context of Fu et al. 's (2006) study is on the level of taxpayer's acceptance of both taxation systems manually using barcode and electronic tax filing. Meanwhile, the context of a study by Wiyonozz et al. (2008) is the taxpayer's acceptable behavior toward the e-Filing system in Indonesia. Furthermore, Hung et al's (2006) study implies a context of the taxpayer's behavioral interest in using Online Tax Filing and Payment System (OTFPS) in Taiwan, while Azmi and Bee's (2010) study is in the context of e-Filing system technology acceptance in Malaysia. As for the context of the study by Ananggadipa (2012), it concerns the use of tax application for entities in Semarang. On the other side, the context of Jankeespasrad et al. 's (2016) study is the behavioral interest in using the eFiling system in South Africa. The previous studies have empirically proven that attitudes have an effect on behavioral interest although there is a study stating the opposite.

In this research, the perceived usefulness is directly proportional to the behavioral interest in using e-Filing system, meaning that the higher the perceived usefulness is given by a person (taxpayer) to the e-Filing system, the higher the person's behavioral interest in using the system. To avoid the rejection of the system developed, 
it is necessary to improve the system to be better and more qualified. With the good and qualified system, the users perceive that the e-Filing system can improve their performance and productivity.

This research also suggests that Indonesian society, especially taxpayers in Malang City, tends to accept the presence of the e-Filing system. Most taxpayers perceive that the application of the e-Filing system becomes an easy and fast way to complete online Annual Tax Return reporting activities so as to improve the taxpayer performance since they no longer need to come to the Tax Office.

\subsubsection{Discussion of Hypothesis 2: The Effect of Perceived Ease of Use on Behavioral Interest in Using E-Filing System}

Perceived Ease of Use in this research is interpreted as the extent to which a person (taxpayer) consider that the use of the e-Filing system will be free of efforts (effortless). If a system is considered easy to use, a person will tend to use it. The testing results obtained empirical evidence that the hypothesis $\left(\mathrm{H}_{2}\right)$ obtained a significance value of 0.113 .

The results are not consistent with the previous studies conducted by Chau et al (2001), Hung et al (2006), Yaghoubi et al (2010), Lee (2009), Azmi and Bee (2010) and Jankespasrad et al (2016), but supports the previous studies conducted by Lawrance and Baridwan (2014) and Aggraini (2012).

Azmi and Bee (2010) and Jankespasrad et al. (2016) are the two studies with inconsistency at most with this research results. Both studies indicate that the higher the ease of use is perceived by a person (user) toward the use of e-Filing system, the greater the willingness and competence of the person to use the system, encouraging positive attitudes toward the system technology.

On another side, Lawrance and Baridwan (2014) and Anggraini (2012) support the results of this research. The context of Lawrance and Baridwan's (2014) study is on the behavioral interest in using Internet Stock Trading while that of Anggraini (2012) is on the behavioral interest in using internet banking. The results of both studies show that perceived ease of use does not significantly affect behavioral interest.
Anggraini (2012) explained that one reason why perceived ease of use has no effect on behavioral interest is that perceived ease of use is not the main factor encouraging customers choose to use internet banking facilities. Meanwhile, according to Lawrance and Baridwan (2014), perceived ease of use does not affect behavioral interest because investors use online trading facilities not based on the ease of use of the facility but rather based on the facility usefulness and need to transact shares independently without the help of brokers.

According to the results of the previous studies above, the researcher presumed that the insignificant effect of the taxpayer's perceived ease of use on the behavioral interest in using eFiling system is due to such a reason. In the context of the use of e-Filing system, it can be explain that because the reporting system of Annual Tax Return has utilized a computerized and automatic system through the website of Directorate General of Taxation, the respondents (taxpayers) are demanded to use the e-Filing system facility in the submission of Annual Tax Return to Directorate General of Taxation. The use of the e-Filing system facility by taxpayers is not based on the ease of use of the facility but rather due to the facility usefulness and need in the reporting of Annual Tax Return independently without the help of the local Tax Office.

\subsubsection{Discussion of Hypothesis 3: The Effect of Perceived Risk on Behavioral Interest in Using E-Filing System \\ Perceived Risk in this research is} defined as the taxpayer's perceived uncertainty and undesired consequences in the submission of Annual Tax Return using the e-Filing system. The testing results obtained empirical evidence that the hypothesis $\left(\mathrm{H}_{3}\right)$ obtained a significance value of 0.088 . The results are not in accordance with the studies conducted by Azmi and Bee (2009) and Lee (2009) but are consistent with Belanger and Carter's (2008) study.

The context of Azmi and Bee's (2009) study is on the behavioral interest in using eFiling system by taxpayers in Malaysia while that of Lee's (2009) study is on the behavioral interest in using the online trading application in Taiwan. Both studies indicate that perceived risks significantly affect behavioral interest.

In contrast, Belanger and Carter (2008) with consistent results to this research show that 
perceived risks have no significant effect on behavioral interest. Belanger and Carter's (2008) study implies a context of trust and risk to the application of the government (e-government) in the US. According to Belanger and Carter (2008), perceived risks have no effect on behavioral interest due to the very low risk of the use of technology in the governmental environment if compared to the risk of using technology in the e-business or e-commerce context.

Based on the previous study results explained above, the researcher presumed that the insignificant effect of the taxpayer's perceived risk on the behavioral interest in using e-Filing system is due to the low and insignificant resulted risk. Besides, the e-Filing system application that becomes the context of this research is similar to the context of the use of e-government technology applied in Belanger and Carter (2008). This is because the context of both studies is at the same level that is the governmental institution environment which does not provide profit-oriented services but public-oriented services. In contrast, the perceived risk of the use of system technology with profit-oriented services such as in ebusiness or e-commerce is more often experienced than that of the use of e-Filing system by taxpayers in the submission of Annual Tax Return. This is because the data submitted are in accordance with the evidence of cut during the tax year reported.

It can be concluded that the risk resulting from the Annual Tax Return e-Filing system does not affect the taxpayer's behavioral interest in using it. This is because the submission of Annual Tax Return through the e-Filing system must be done by taxpayers themselves in accordance with the Taxpayer Identification Number $(N P W P)$. In addition, each taxpayer must have e-fin and email address used as the basis for applying the e-Filing system so that the taxpayer's data will be more secure.

\subsubsection{Discussion of Hypothesis 4: The Effect of Perceived Benefit on Behavioral Interest in Using E-Filing System}

Perceived Benefit in this research is interpreted as the taxpayer's perception or feeling of increased comfort, cost saving, and timesaving in the submission of Annual Tax Return using the e-Filing system. According to the testing results, the hypothesis $\left(\mathrm{H}_{3}\right)$ empirically obtained a significance value of 0.001 , showing consistent results with the previous studies conducted by Azmi and Bee (2010) and Lee (2009). The context of Azmi and Bee's (2009) study is on the behavioral interest in using eFiling system by taxpayers in Malaysia while that of Lee's (2009) study is on the behavioral interest in using the online trading application in Taiwan.

Empirically, the previous studies have proven that perceived benefits have an effect on behavioral interest, and so do this research. Thus, it can be concluded that, overall, the e-Filing system service applied by the Directorate General of Taxation has been able to provide great benefits for users (taxpayers) of the eFiling system. Furthermore, the e-Filing system has been providing solutions to the system users (taxpayers) with its fast and easy service in the submission of Annual Tax Return without having to come and queue to the Tax Office. By these solutions, taxpayers can certainly save their money and time since they can report Annual Tax Return independently without coming to the Tax Office. Another benefit provided by the eFiling system is the openness or transparency of the Annual Tax Return reporting for all taxpayers.

\subsubsection{Discussion of Hypothesis 5: The Effect of Perceived Behavioral Control on Behavioral interest in using E-Filing System \\ Perceived Behavioral Control in this} research is defined as the ease or difficulty in reporting Annual Tax Return through e-Filing system technology. The testing results obtained empirical evidence that the hypothesis $\left(\mathrm{H}_{3}\right)$ showed a significance value of 0.001 . The results of this research are in line with the previous studies conducted by Rana et al. (2015), Suki and Ramayah (2010) and Hastuti et al. (2014). Rana et al. (2015) implies a context on the application of e-government technology in India using Decomposed Theory of Planned Behavior (DTPB) approach. On the other side, the research context of Suki and Ramayah (2010) is on the application of e-government technology in Malaysia. Differently, the study of Hastuti et al. (2014) concerns the use of Decomposed Theory of Planned Behavior (DTPB) approach in the application of e-Filing system technology in Indonesia. The previous studies explained above empirically have proven that perceived 
behavioral control has an effect on behavioral interest.

In this research, the perceived behavioral control is directly proportional to the behavioral interest in using the e-Filing system. That is, the higher the perceived behavioral control is given by a person (taxpayer) over the e-Filing system, the higher the person's behavioral interest in using it will be. This research concludes that Indonesian society, especially taxpayers in Malang City, tends to be more satisfied with the use of the e-Filing system in reporting their Annual Tax Return because the system is easy to use. This indicates that in the future, it is expected that there will be more taxpayers sincerely reporting their Annual Tax Return by using the e-Filing system technology, that is by visiting the website provided by Directorate General of Taxation: www.djponline.go.id.

\section{E. CONCLUSION AND SUGGESTION}

\subsection{Conclusion}

Based on the results of this research, it can be concluded that Perceived Usefulness, Perceived Benefit, Perceived Behavioral Control have an effect on Behavioral Interest in using e-Filing system. Meanwhile, Perceived Ease of Use and Perceived Risk are proven not to affect Behavioral Interest in using e-Filing system.

This suggests that most taxpayers in Malang City have accepted and felt comfortable with the presence of new technology in the world of taxation, especially in the submission of Annual Tax Return. Since the presence of the eFiling system, the taxpayers have been easier in reporting their Annual Tax Return since they no longer need to come to the Tax Office.

The results of this study also show that Indonesian society, especially taxpayers in Malang City, believes that the e-Filing system application can improve their performance and productivity. It means that most taxpayers in Malang City have accepted the presence of eFiling system technology for their Annual Tax Return reporting since they experience the ease, benefit, and effectiveness of the e-Filing system. Furthermore, the research results also suggest that the application of information system technology, i.e. the application of e-Filing system in Indonesia, especially in Malang City, does not provide high risks on behavioral interest in using it. Additionally, the perceived ease of use also does not significantly affect the taxpayer's behavioral interest in using the eFiling system facility. This is because the use of the e-Filing system facility by taxpayers is not based on the ease of use of the facility but rather due to the facility usefulness and need in the reporting of Annual Tax Return independently without having to come to the local Tax Office. Above all, perceived usefulness, perceived ease of use, perceived risk, perceived benefit and perceived behavioral control by a person (taxpayer) in using e-Filing system will encourage an increased behavioral interest in using information system technology in the future.

\subsection{Suggestion}

It is recommended that further research with the same research topic and subject should be undertaken with the following improvements:

Firstly, further researchers need to prolong the research time. This is to allow for more sufficient and clear explanation about the studied topic and subject. Based on this suggestion, it is also hoped that further researchers can increase the number of respondents (taxpayers) from various regions so that the desired generalization can be obtained.

Secondly, further researchers need to expand the DTPB research model on different cultures and individuals, for example, conducting such a research in the wider scope.

Thirdly, further researchers are expected to add and develop the research variables with the DTPB model approach in various contexts, not only in the context of e-Filing or e-government context. This is to make the research more useful for developing information system technology in the face of the globalization era that is full of information technology.

\section{F. REFERENCES}

Amalia, S. (2010). Persepsi Pegawai Pajak terhadap Pemanfaatan Teknologi Informasi pada Kinerja Individual (Studi Kasus pada KPP Pratama Tegal) Skripsi Universitas Diponegoro Semarang

Ananggadipa, S. (2012). Studi Empiris Pada Penggunaan Aplikasi Pajak: Integrasi Theory of Planned Behavior dan Technology Acceptance Model. Skripsi, Universitas Diponegoro, Semarang. 
Anggraini, R.Y. 2012. Penerimaan internet banking: Pendekatan technology acceptance model yang dimodifikasi. Skripsi. Malang: Jurusan Akuntansi FEB UB.

Undang-Undang Nomor 16 tahun 2009 tentang Ketentuan Umum dan Cara Perpajakan.

Ghozali, I. (2012). Aplikasi Analisis Multivariate Dengan Program IBM SPSS 20 (Enam ed.). Semarang: Badan Penerbit Universitas Diponegoro.

Hasyim. (2009). Teori Tindakan Beralasan dan Teori Perilaku Perencanaan dalam Pengadopsian Sistem Teknologi Informasi. Politeknik Negeri Ujung Pandang. Ujung Pandang.

Jogiyanto, H.M. 2007. Sistem Informasi Keperilakuan Edisi Revisi. Yogyakarta: ANDI.

Jogiyanto, H. M. (2010). Metodologi Penelitian Bisnis Salah Kaprah dan PengalamanPengalaman (Edisi Pertama). Yogyakarta: BPFE-Yogyakarta.

Lawrence, S. M., dan Baridwan, Z. 2016. Determinan Sikap dan Minat Keperilakuan Individu Menggunakan Internet Stock Trading.

Mardiasmo. 2011. Perpajakan Edisi Revisi. Yogyakarta : CV. Andi Offset

Riduwan. 2009. Metode dan Teknik Menyusun Tesis. Bandung : Alfabeta

Saraswati, P. \& Baridwan, Z. 2013. Penerimaan sistem e-commerce: pengaruh kepercayaan, persepsi manfaat dan persepsi risiko. Skripsi. Malang: Jurusan Akuntansi Fakultas Ekonomi dan Bisnis Universitas Brawijaya.

Sugiyono. 2015. Metode Penelitian Kuantitatif, Kualitatif dan R\& D. Bandung : Alfabeta

Wiyono, A. S., Ancok, D., \& Hartono, J. (2008). Aspek Psikologis pada Implementasi Sistem Teknologi Informasi E-Indonesia Initiative 2008. Jakarta. 